\title{
LAND-USE CHANGE SCENARIOS OF CHOSEN SMALL WATER BODY - PUBLIC PARTICIPATION FOR A NEW REALITY
}

\author{
Weronika MAŚLANKO *, Joanna SENDER * and Agnieszka KUEAK *
}

* University of Life Science in Lublin, B. Dobrzańskiego Street 37, Lublin, Poland, PL-20-262, weronika.maslanko@up.lublin.pl, joanna.sender@up.lublin.pl, a.k.ulak@wp.pl

KEYWORDS: building scenario, suburban area, user needs.

DOI: 10.1515/trser-2015-0082

\section{ABSTRACT}

The object of this study was a small water body adjacent to the Zemborzycki Reservoir. The aim of the study was to find an optimal way of management of the small water body's surroundings based on scenario building and public participation. The three following scenarios of the small water body's surroundings' management with a leading role were used: a) ecological and educational, b) representative and recreational, and c) left in its current form. As a result of the public participation conducted in 2011, it was shown that the ecological and educational scenario is the most optimal for the respondents; and in 2012, implementation had been undertaken. In the decision-making process, a public participation seems to play an important role because actions are accepted, thus fulfilling needs of most users and allowing for identification of the society within a given place.

RESUMEN: Escenarios de cambio de uso de suelo en un pequeño cuerpo de agua participación ciudadana en la creación de una nueva realidad.

El objeto de este estudio fue el pequeño cuerpo de agua adyacente al embalse de Zemborzycki. El objetivo fue elegir el tipo óptimo de manejo de dicho cuerpo, basado en la construcción de escenarios y la participación ciudadana. Los tres escenarios más significativos de manejo del entorno del cuerpo de agua son: a) ecológico y educativo; b) representativo y recreativo; y c) como se encuentra y se usa actualmente. Como resultado de la participación ciudadana llevada a cabo en 2011, el escenario ecológico y educativo resultó ser óptimo para los encuestados, mismo que se implementó en 2012. En el proceso de la toma de decisiones, la participación ciudadana parece desempeñar un papel importante, porque gracias a ésta se aceptaron las medidas adoptadas, se cubrieron las necesidades de la mayoría de los usuarios y se identificó un lugar específico para la sociedad en el proceso de manejo.

REZUMAT: Scenariile privind schimbarea utilizării terenurilor a corpurilor mici de apă - participarea cetățenească la crearea unei noi realităţi.

Obiectul acestui studiu a fost corpul mic de apă adiacent la rezervorul Zemborzycki. Scopul studiului a fost alegerea optimă de gestionare a mediului corpului mic de apă, pe baza elaborării de scenarii şi participarea cetăţenească. Cele trei scenarii diferite mai semnificative de gestionarea a mediului corpului mic de apă sunt: a) ecologic şi educaţional, b) reprezentativ şi recreativ, c) aşa cum se găseşte şi se foloseşte în prezent. Ca urmare a participării cetăţeneşti care a avut loc în anul 2011, scenariul ecologic şi educaţional s-au dovedit a fi cea mai optimă pentru respondenţi, şi în anul 2012 punerea în aplicare a fost efectuată. Participarea cetățenească la procesul de luare a deciziilor pare să joace un rol important, datorită acestui fapt sunt acceptate măsurile adoptate, nevoile majorităţii utilizatorilor sunt acoperite şi se permite identificarea societății cu un anumit loc. 


\section{INTRODUCTION}

In times of declining water resources and their progressive degradation, each aquatic ecosystem should be investigated because of its values. An important meaning in enriching water resources have small water bodies (Hajdu and Kelemen, 2009), often missed in research. In addition to the poor quality of surface waters, there are problems associated with the management of many reservoirs' surroundings, especially in suburban areas (Chełmicki, 2012).

Water reservoirs are one of the environmental elements of importance with their valuable function, like water retention for municipalities (Mioduszewski, 2006; Sender and Kułak, 2010). Furthermore, they are perceived as high-value enclaves of the natural environment, as well as objects with recreation function for the rest (Mioduszewski, 1999; Celiński et al., 2001). Small water bodies are an integral part of the rural and urban landscape, significantly enriching their biodiversity (Szpakowska and Życzyńska-Bałoniak, 1994; Hłyńczak et al., 1995; Patro and Zubala, 2010), as well as in the river valleys (Kopeć, 2007).

Because of small size, small water bodies, more often than other reservoirs, are exposed to drying and eutrophication processes that cause disturbances in the species' composition and their degradation (Kalbarczyk, 2003; Kuczera and Misztal, 2007).

The meaning of research methods based on scenario building is increasing (Verburg et al., 2006), particularly in times of global warming and climate change monitoring and modelling landscape dynamics gained in significance (Houet et al., 2010). Visualization of scenarios is a great way to discover and predict inhabitants' needs. Gibon et al. (2010) illustrates the need of integration and participation that considers socio-ecological processes in the modelling and elaboration of scenarios.

The aim of this study was the choice of an optimal way of management of the small water body's surroundings based on scenario building and public participation.

\section{MATERIAL AND METHODS}

\section{Study area}

A small water body being researched is located in the administrative boundaries of the Lublin city, in the surroundings of the Zemborzycki Reservoir with leading recreational functions. This area belongs to the Bystrzyca River valley (Fig. 1). In the area development plan, this area was designed as a green area, whereas local plans of spatial development did not include it.

In 2007, after the construction of the bike and walk path on a substantial section of the western shore of the Zemborzycki Reservoir, a separate small water body was created in the immediate vicinity of the reservoir as a result of cutting off one of its bays after the construction works of the embankment; but it is still staying connected with the reservoir by a concrete culvert.

Instead of localization of the small water body in the city and fields, it is intensively used as an agricultural constitute for a significant part of the catchment.

From the east, a single-family housing is a dominant way of land use, and on the eastern part there is the Zemborzycki Reservoir.

The small water body has only 0.13 hectares and is a land depression constantly filled with water. Up until 2010, it acted as a receiver of pollutants and was also used as an illegal dumping ground. In that state it did not have any natural and landscape values. 


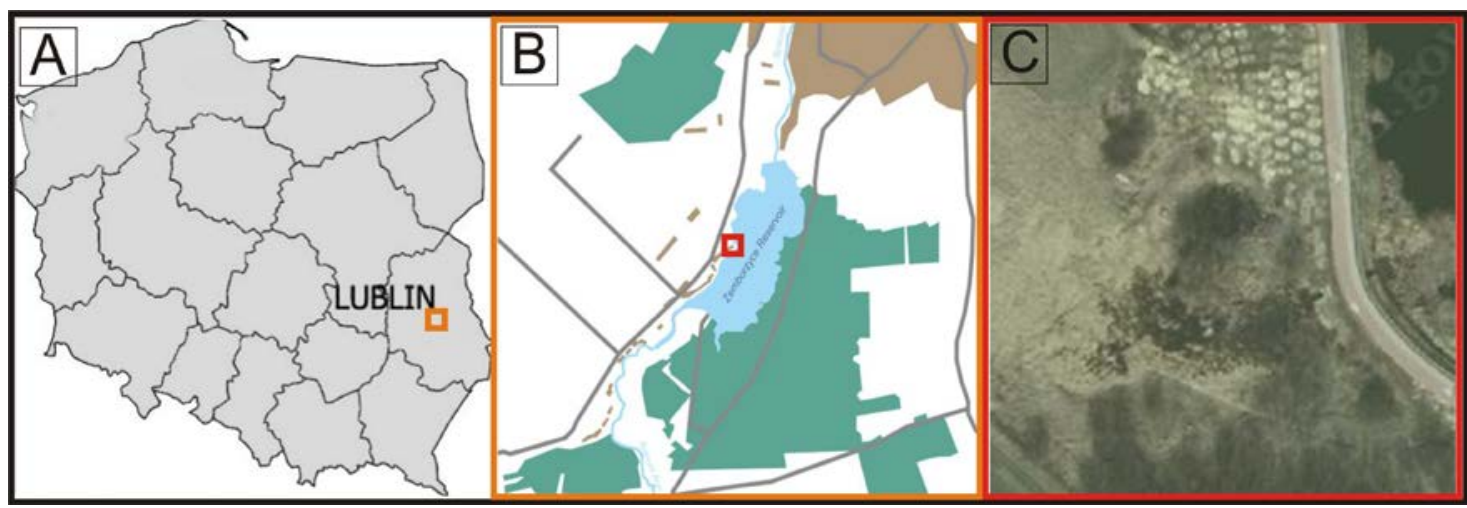

Figure 1: Localization of small water body under study.

\section{Sampling analysis and measurements}

In the concept development process of the small water body's management, several studies were conducted; because of this, it was possible to carefully study the specificity of the area and create an optimal solution important to the interests of nature and landscape conservation (Sender and Kułak, 2010; Kułak et al., 2011).

Different scenarios of management and functioning of the small water body area, as well as its surroundings, were based on earlier questionnaire surveys carried out in the surrounding area of the Zemborzycki Reservoir, regarding the needs and recreation preferences over water areas (Kułak and Waryszak, 2010; Kułak, 2013).

A public consultation that was carried out by a questionnaire of 80 people resting nearby the object under the study was the next step of our research. We wanted to find out the demands of the people visiting the study area and involved its users.

The questionnaire consisted of two parts. The first part included a graphic presentation (photographs) and descriptions of the object, concerning its current status, functioning and use, as well as values and problems. In the second part, three scenarios of different ways of management were presented to respondents: a) ecological and educational, b) representative and recreational, c) left in its current form. For each scenario, the descriptive functional and spatial program (Fig. 2) a location plan (a top view) and four 3D visualizations were presented.

Next, people were asked to tell us which of the presented scenarios is preferred by them and if it would be of worth to conduct the implementation. In case the respondents did not agree with any of the presented options, they had also a possibility of not pointing out any particular scenario, as well as the ability to free expression. Choice was written down in each questionnaire given to the respondents. 


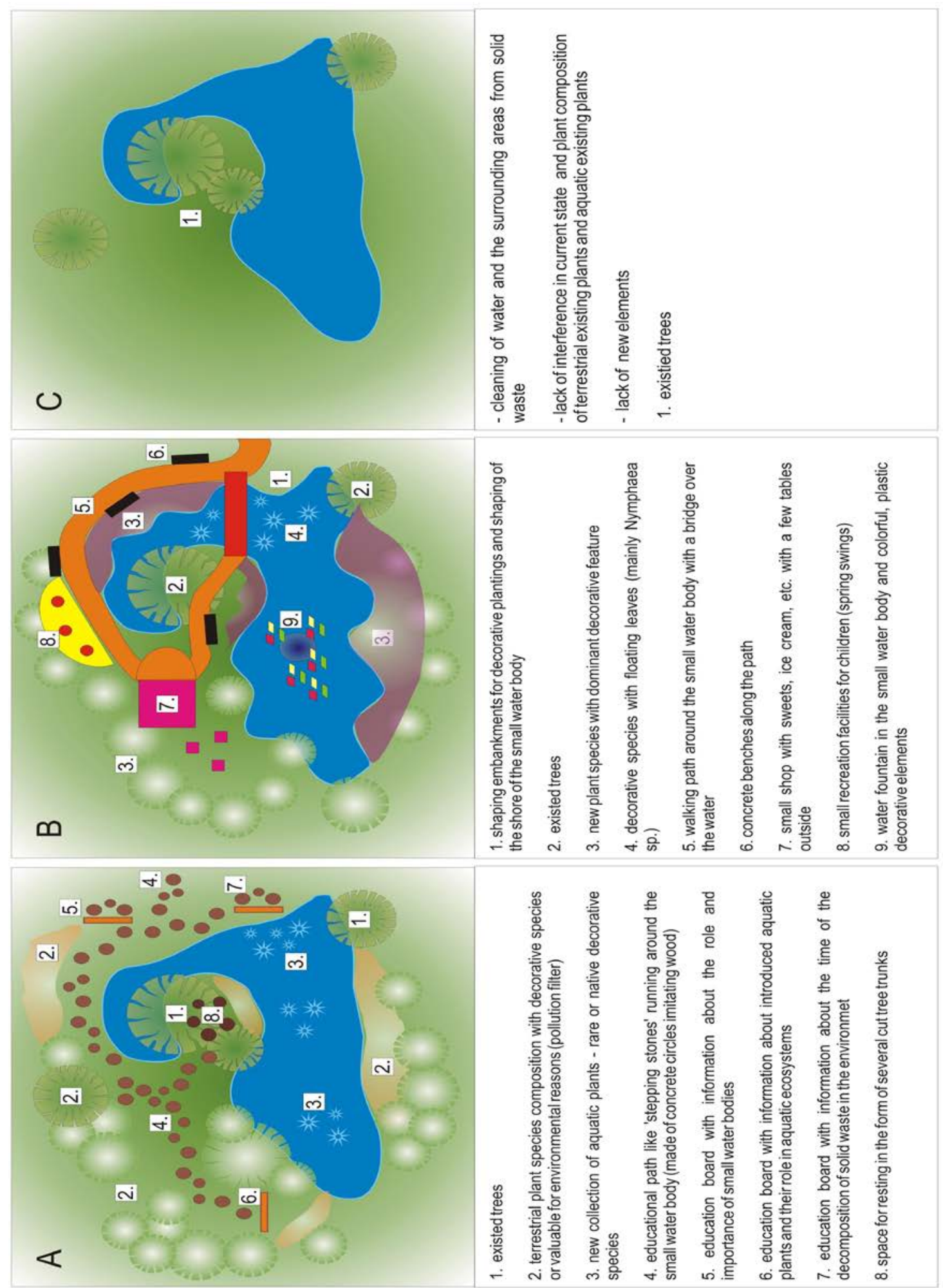

Figure 2: Visualization of three different scenarios of the small water body. 
Each concept included five categories of information about the following: land use around the small water body vegetation, elements of infrastructure, materials used, and a target group (Tab. 1).

Table 1: Three scenarios of different ways of management: a) ecological and educational, b) representative and recreational, c) left in its current form.

\begin{tabular}{|c|c|c|c|}
\hline & $\begin{array}{l}\text { The concept of expanded } \\
\text { ecological and educational } \\
\text { function }\end{array}$ & $\begin{array}{l}\text { The concept of expanded } \\
\text { representative and recreational } \\
\text { function }\end{array}$ & $\begin{array}{l}\text { The concept } \\
\text { of leaving } \\
\text { its current form }\end{array}$ \\
\hline$\underset{\mathscr{U}}{\mathbb{2}}$ & $\begin{array}{l}\text { Assumptions: } \\
\text { - cleaning of water and the } \\
\text { surrounding areas from } \\
\text { solid waste; } \\
\text { - stabilization of the water } \\
\text { level in the small water } \\
\text { body (valve on the conduit); } \\
\text { - a small interference with } \\
\text { the natural terrain and } \\
\text { shores of the small water } \\
\text { body, including necessary } \\
\text { levelling for the } \\
\text { introduction of a walk and } \\
\text { bike path. }\end{array}$ & $\begin{array}{l}\text { Assumptions: } \\
\text { - cleaning of water and the } \\
\text { surrounding areas from solid } \\
\text { waste; } \\
\text { - stabilization of the water level in } \\
\text { the small water body (valve on } \\
\text { the conduit); } \\
\text { - a great interference with the } \\
\text { natural terrain and shores of the } \\
\text { small water body, including } \\
\text { levelling of the ground, shaping } \\
\text { embankments for decorative } \\
\text { plantings and shaping of the } \\
\text { shore of the small water body } \\
\text { according to the project. }\end{array}$ & $\begin{array}{l}\text { Assumptions: } \\
\text { - cleaning of water and } \\
\text { the surrounding areas } \\
\text { from solid waste; } \\
\text { - lack of water level } \\
\text { stabilization in the } \\
\text { small water body } \\
\text { (possible periodic } \\
\text { drying); } \\
\text { - lack of interference } \\
\text { with the natural } \\
\text { terrain and shores of } \\
\text { the small water body. }\end{array}$ \\
\hline 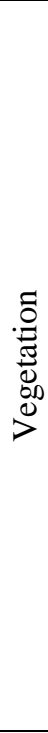 & $\begin{array}{l}\text { - a small interference in the } \\
\text { current state and plant } \\
\text { composition of existed } \\
\text { vegetation; } \\
\text { - removal of a small amount } \\
\text { of plants that obstruct or } \\
\text { prevent the free use of land; } \\
\text { - enrichment of terrestrial } \\
\text { plant species' composition } \\
\text { of decorative species or } \\
\text { value for environmental } \\
\text { reasons (pollution filter); } \\
\text { - leaving most of the existing } \\
\text { aquatic plants and the } \\
\text { implementation of a new } \\
\text { collection of aquatic plants } \\
\text { - rare or native decorative } \\
\text { species. }\end{array}$ & $\begin{array}{l}\text { - a great interference in current } \\
\text { state and plant composition of } \\
\text { existed vegetation; } \\
\text { - } 80 \% \text { removal of existing } \\
\text { vegetation; } \\
\text { - planting new plant species with } \\
\text { dominant decorative feature; } \\
\text { - removal part of existing aquatic } \\
\text { plants (especially underwater); } \\
\text { - planting of decorative species } \\
\text { with floating leaves (mainly } \\
\text { Nymphaea sp.). }\end{array}$ & $\begin{array}{l}\text { - lack of interference } \\
\text { in the current state } \\
\text { and plant } \\
\text { composition of } \\
\text { existing terrestrial } \\
\text { plants; } \\
\text { - lack of interference } \\
\text { in the current state } \\
\text { and plant } \\
\text { composition of } \\
\text { existing aquatic } \\
\text { plants. }\end{array}$ \\
\hline
\end{tabular}


Table 1 (continued): Three scenarios of different way of management: a) ecological and educational, b) representative and recreational, c) left in its current form.

\begin{tabular}{|c|c|c|c|}
\hline 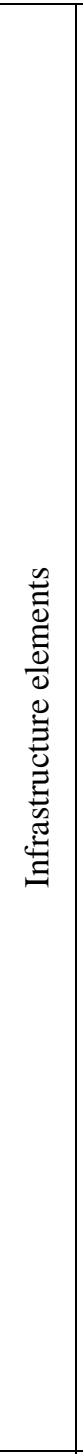 & $\begin{array}{l}\text { - creation of an } \\
\text { educational path like } \\
\text { "stepping stones" } \\
\text { running around the } \\
\text { small water body } \\
\text { (made of concrete } \\
\text { circles imitating } \\
\text { wood); } \\
\text { - the placing of three } \\
\text { education boards } \\
\text { located at the } \\
\text { educational path. The } \\
\text { first with information } \\
\text { about the role and } \\
\text { importance of small } \\
\text { water bodies. The } \\
\text { second with } \\
\text { information about } \\
\text { introduced aquatic } \\
\text { plants and their role in } \\
\text { aquatic ecosystems. } \\
\text { The third board is } \\
\text { designed for the } \\
\text { youngest users, made } \\
\text { up of rotating } \\
\text { elements that will } \\
\text { contain information } \\
\text { about the time of the } \\
\text { decomposition of solid } \\
\text { waste in the } \\
\text { environment; } \\
\text { - creation of space for } \\
\text { resting in the form of } \\
\text { several cut tree trunks, } \\
\text { set under the largest } \\
\text { tree }\end{array}$ & $\begin{array}{l}\text { - creation of paved walking path around } \\
\text { the small water body with a bridge } \\
\text { over the water; } \\
\text { - setting concrete benches along the } \\
\text { path; } \\
\text { - location of a small shop with sweets, } \\
\text { ice cream, etc. with a few tables } \\
\text { outside; } \\
\text { - setting up a small recreation facility } \\
\text { for children (spring swings); } \\
\text { - introduction of a water fountain into } \\
\text { the small water body and colorful, } \\
\text { plastic decorative elements. }\end{array}$ & • lack of new elements. \\
\hline 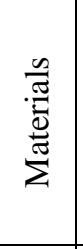 & $\begin{array}{c}\text { • natural or imitating } \\
\text { natural - wood, stone, } \\
\text { gravel, bark, concrete } \\
\text { with wood-effect, etc.; } \\
\text { • no color contrast, low- } \\
\text { key, natural. }\end{array}$ & $\begin{array}{l}\text { - metal or artificial - plastic, resin, gum; } \\
\bullet \text { contrast colours. }\end{array}$ & $\begin{array}{l}\text { - lack of putting new } \\
\text { elements. }\end{array}$ \\
\hline 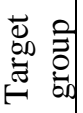 & Each age group. & $\begin{array}{l}\text { Each age group with the main children } \\
\text { function. }\end{array}$ & $\begin{array}{l}\text { Difficult access - limited } \\
\text { use. }\end{array}$ \\
\hline
\end{tabular}




\section{RESULTS AND DISCUSSION}

Visualizations of three land use management scenarios were prepared to collect information about users' needs (Fig. 2).

The interviews were suitable to obtain information about standards of the way of spending free time. The action was received positively, respondents willingly took part in the survey, expressing the joy of interest in this place that was up to now quite neglected. They appreciated the fact that their opinion is important for designers and will have a significant impact on the development of a concrete implementation.

Of the basic conducted questionnaire survey, the vast majority of respondents chose the first scenario that was chosen by $62 \%$ of respondents (Fig. 3.)

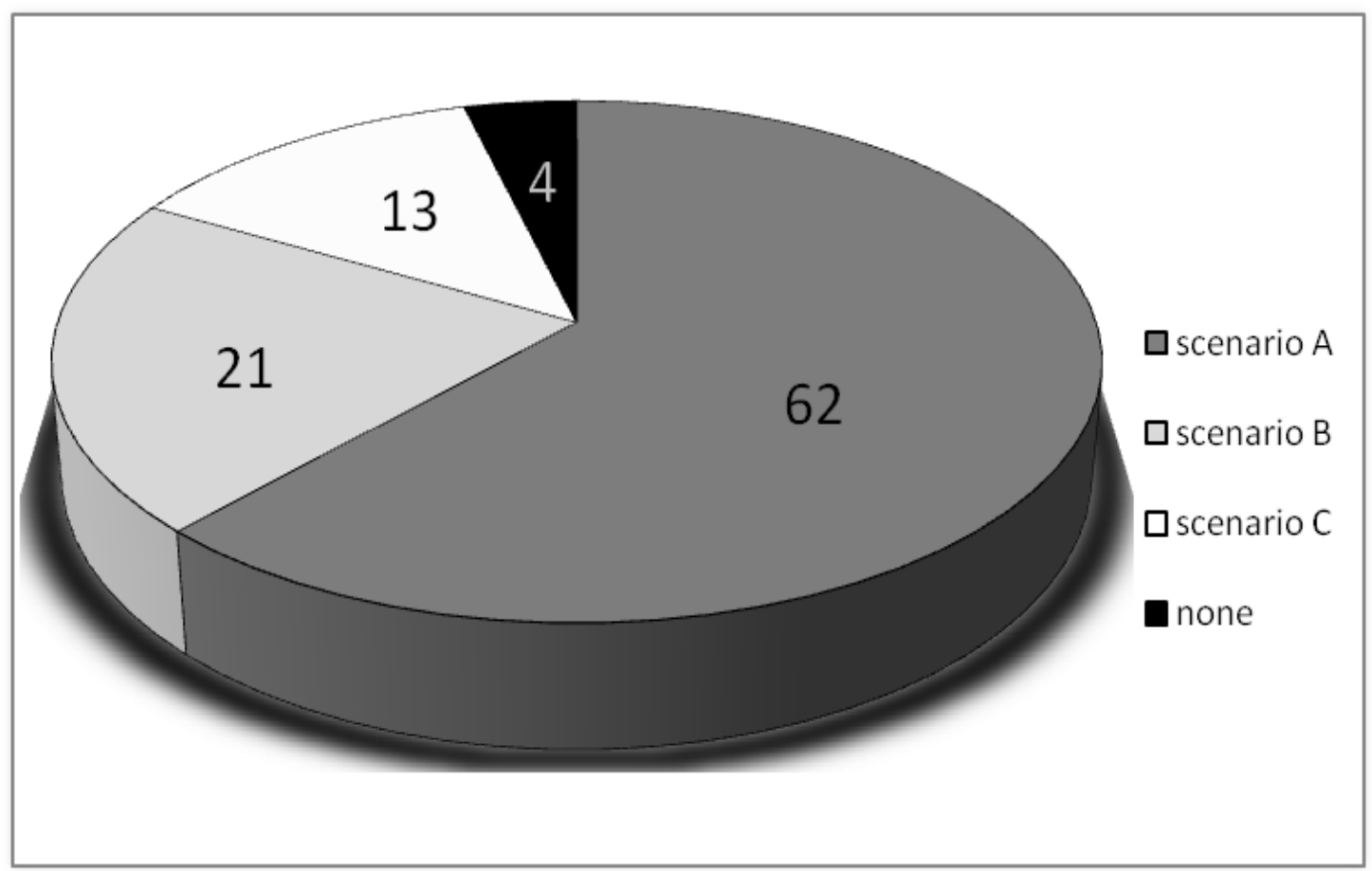

Figure 3: Percentage share of chosen by respondents’ scenarios.

The representative and recreational scenario was chosen by $21 \%$ of respondents, whereas $13 \%$ chose leaving the current state of the area. Only $4 \%$ of asked people were not interested in any future works in this area. The results revealed the importance of a piece of nature in suburban areas. Chosen by respondents, the ecological and educational scenario of the small water body management was implemented in 2012 (Figs. 4a-d). Results showed that the project of revitalization of the small water body was very important for interviewees. The area surrounding the small water body belongs to the Lublin city, and that is why the work was supported by the Department of Natural Protection in the Municipality Lublin. 


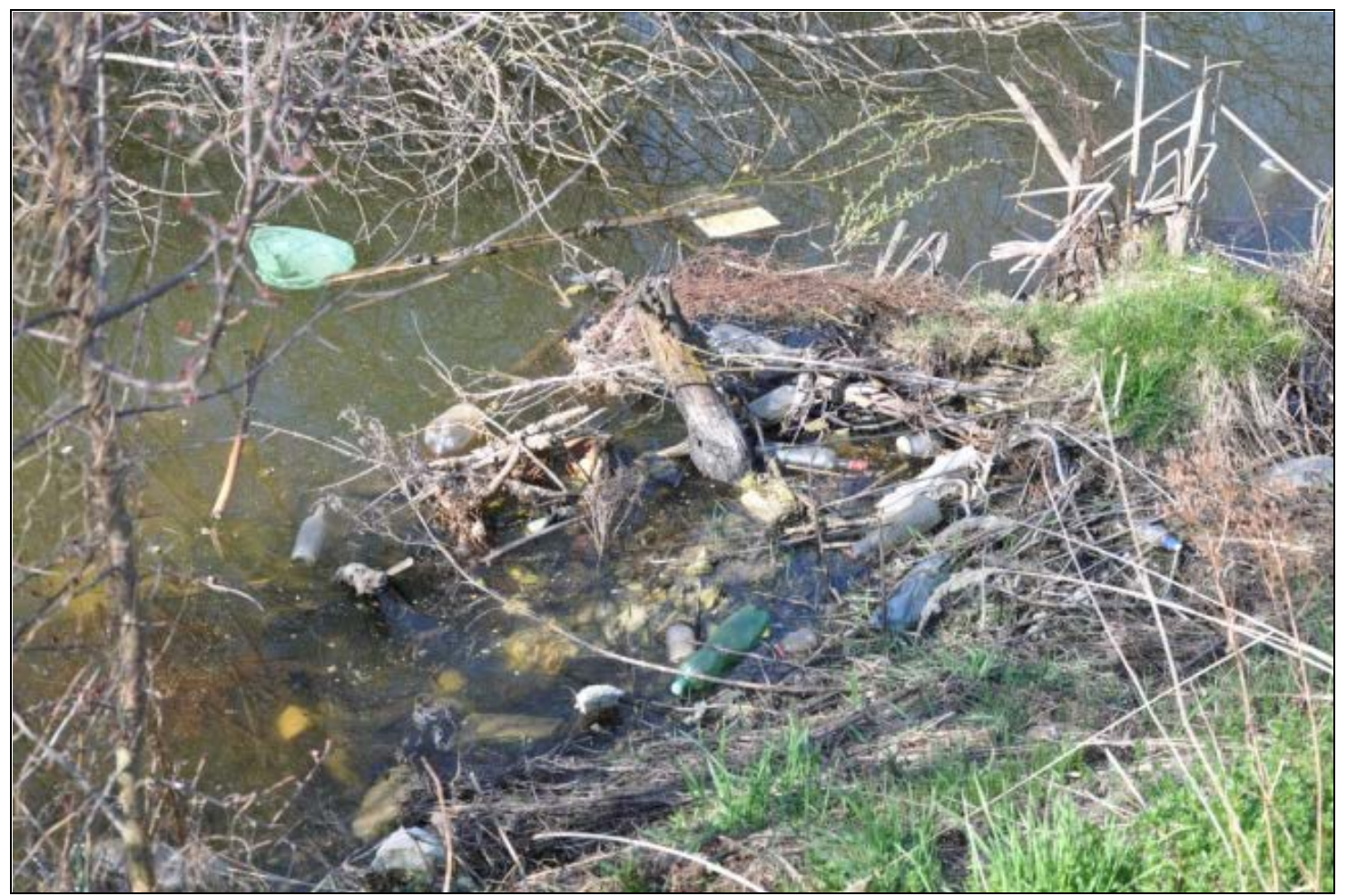

Figure 4a: Area under the study before (2011).

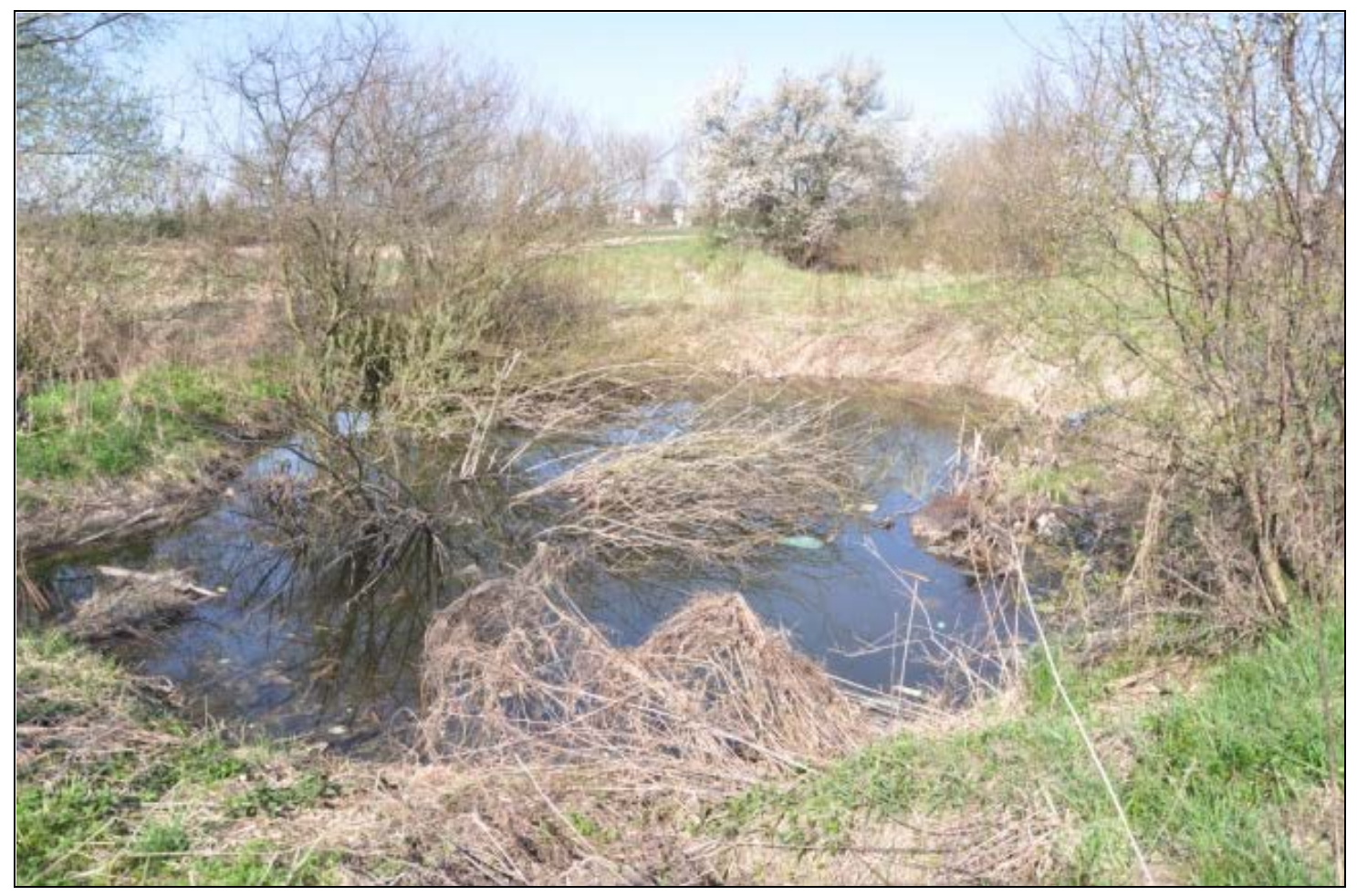

Figure 4b: Area under the study before (2011). 


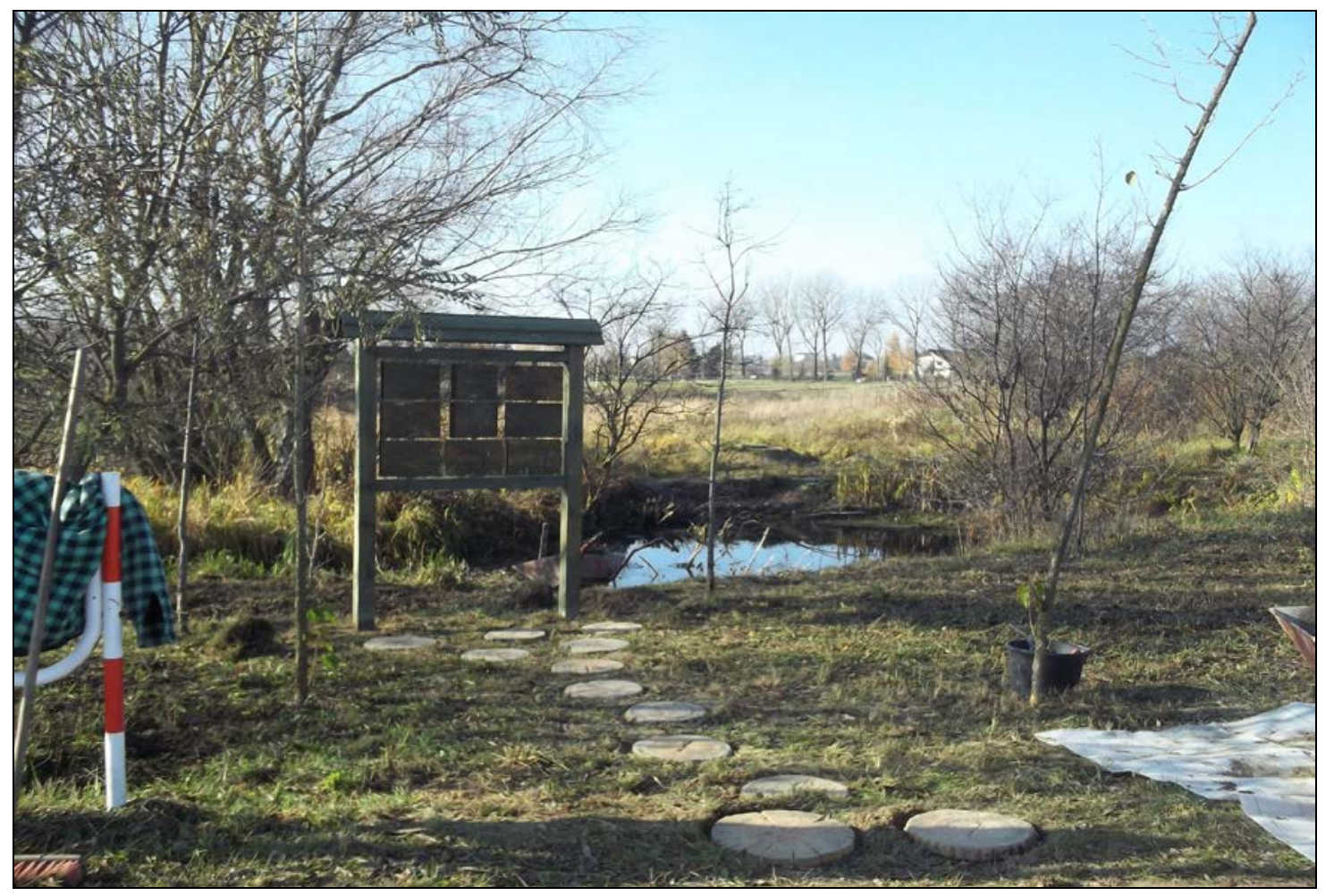

Figure 4c: Area after the revitalization (2012).

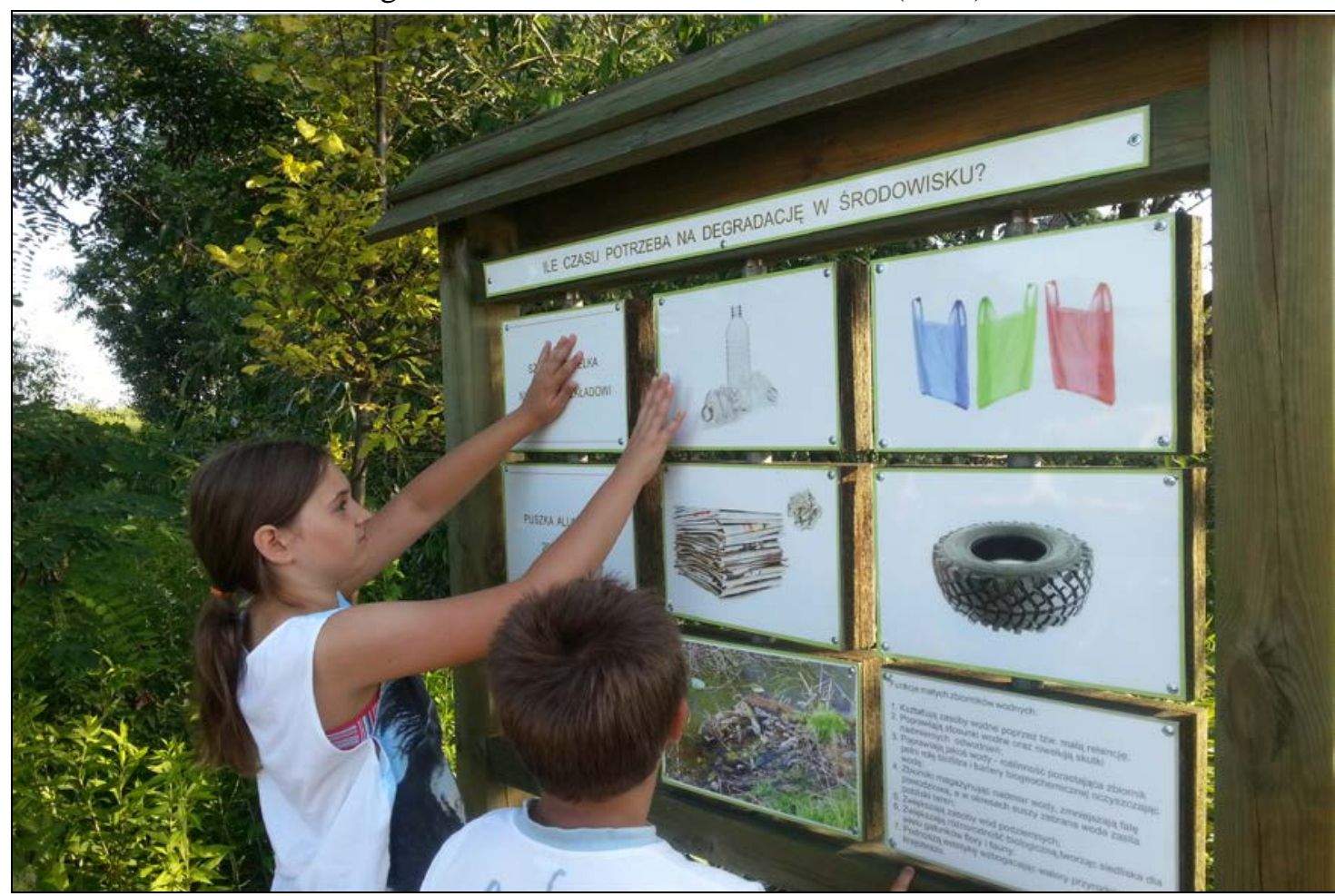

Figure 4d: Area after the revitalization (2012). 


\section{DISCUSSION}

Small water bodies have a great biological function. Together with the surrounding vegetation and soils, they constitute an ecological system for wild flora and fauna species (Goławski and Kasprzykowski, 2007). Simultaneously, they provide an increased biodiversity of the surrounding area (Kalbarczyk, 2003). Furthermore, small water bodies affect the level of groundwater and soil water management of the surroundings areas (Fiedler, 1997). They constitute suitable habitats for the development of aquatic vegetation - macrophytes (Hartog and Segal, 1964; Cook, 1983; Wołek, 1996; Maślanko et al., 2011). Macrophytes in the small water body shape abiotic and biotic conditions, influencing mainly on the fertility of the waters, plants and animals species composition, provide a place of feeding, breeding and refuge for many aquatic invertebrates and fish; as well as habitats for avifauna (Kornijów and Radwan, 2000). Moreover, they can act as a barrier in the form of capturing and neutralizing a filter of elements flowing from the catchment (Wiater, 2005). Probably because of planting, many different submerged and emergent macrophytes species, the biodiversity of the small water body under the study will increase.

For landscape architects, it is crucial to understand peoples' needs and expectations, because they are responsible for creating a new reality. The best way to understand them is to allow people to express their opinions. Buchecker et al. (2003) found that direct participation in the landscape changes raises residents' responsibility for their living environment, creates basis for sustainable development and enables social and cultural integration as the consequence of higher interest in regional and national politics. Participation in environmental activities has been acknowledged to play a role in increasing scientific literacy in a broader sense (Conrad and Hilchey, 2010), as helping to promote a reconnection between people and nature (Devictor et al., 2010; Hobbs and White, 2012), as well as raising awareness of environmental issues (Brossard et al., 2005; Jones-Walters and Cil, 2011). The local space users are usually addressed by interviews made in the field (Hinterberger et al., 2000; Volk, 1992). To obtain general valid information, a high number of interviews need to be conducted (Janovsky and Becker, 2003). In the decision-making process, a public participation seem to play an important role, because thanks to it, taken actions are accepted, thus fulfilling needs of most users and allowing for identification of the society with a given place. Thanks to a public participation, a new and improved reality, balancing the needs of society and nature conservation can be shaped.

A concept of revitalization of small water bodies in suburban areas is an example of creating "green areas" in the city. It provides possibilities of outdoor recreations for Lublin inhabitants. Designing of this kind of recreation should be accomplished so that the sustainability of these areas is preserved and it should provide the future generation with the opportunity to enjoy the natural values of the outdoor recreation at an even higher level (Bell, 2007). Natural attractions in suburban areas are one of the recreational resources in ecotourism and these attractions are located in most of rural areas in the world. Conducted research pointed out that ecological and educational types of scenarios are needed. We concluded that probably the Zemborzycki Reservoir fulfils an intensive type of recreation in Lublin city, whereas people also need some enclaves of nature close to their homes. 
ACKNOWLEDGEMENTS

The authors thank to the reviewers for their input. 


\section{REFERENCES}

1. Bell S., 2007 - Design for outdoor recreation (2nd edition), Taylor and Francis, London, 1-232.

2. Brossard D., Lewenstein B. and Bonney R., 2005 - Scientific knowledge and attitude change: The impact of a citizen science project, International Journal of Science Education, 27, 10991121.

3. Buchecker M., Hunziker M. and Kienast F., 2003 - Participatory landscape development: overcoming social barriers to public involvement, Landscape and Urban Planning, 64, 29-46.

4. Celiński F., Czylok A. and Kubajak A., 2001 - Przewodnik przyrodniczy po Dąbrowie Górniczej/The nature guide to Dąbrowa Górnicza, Wydawnictwo Kubajak, Krzeszowice, 1-72. (in Polish)

5. Chełmicki W., 2012 - Woda, zasoby, degradacja, ochrona/Water, resources, degradation, conservation, Wydawnictwo Naukowe, PWN, 1-305. (in Polish)

6. $\quad$ Cook R. E., 1983 - Clonal plant populations, Annals of Science, 71, 244-253.

7. Conrad C. C. and Hilchey K. G., 2010 - A review of citizen science and community based environmental monitoring: issues and opportunities, Environmental Monitoring and Assessment, 176, 273-291.

8. Devictor V., Whittaker R. J. and Beltrame C., 2010 - Beyond scarcity: Citizen science programmes as useful tools for conservation biogeography, Diversity and Distribution, 16, 354362.

9. Fiedler M., 1997 - Bilanse wodne zlewni śródpolnych oczek wodnych na terenie zdrenowanym/Catchment's water balances of agriculture small water bodies on a drained area, PhD Disertation, Department of Land Reclamation and Environmental Development UP Poznań, 100. (in Polish)

10. Gibon A., Sheeren D., Monteil C., Ladet S. and Balent G., 2010 - Modelling and simulating change in reforesting mountain landscapes using a social-ecological framework, Landscape Ecology, 25, 265-283.

11. Goławski A. and Kasprzykowski Z., 2007 - Znaczenie starorzeczy w kształtowaniu różnorodności przyrodniczej doliny Bugu/The importance of floodplains in shaping of the natural diversity of the Bug River valley, Wyd. Akademii Podlaskiej, Siedlce, 104-108. (in Polish)

12. Hajdu Z. and Kelemen A., 2009 - An ecological reconstruction model of a small tributary, the Dorman Creek, Acta Oecologica Carpatica, II, 199-204.

13. Hartog C. and Segal S., 1964 - A New classification of the water plant communities, Acta botanica neerlandica, 13, 3, 367-393.

14. Hinterberger B., Arnberger A., Brandenburg C. and Cermak P., 2000 - Besucherstromanalyse für den Wiener Bereich des Nationalpark Donau-Auen/Lobau - GIS-Implementierung und erste Ergebnisse, in Angewandte Geographische Informationsverarbeitung, XII, Beiträge zum AGITSymposium Salzburg 2000, Stobl J., Blaschke T. and Griesebner G. (eds), 216-227. (in German)

15. Hłyńczak A. J., Poleszczuk G., Możdżer A., Słupińska A. and Deptuła W., 1995 - Ekologiczne znaczenie zbiorników wodnych w aglomeracjach miejskich na przykładzie Rusałki w Szczecinie/Ecological role of water reservoirs in an Urban agglomeration on the example of Rusalka in Szczecin, Aura, 2, 9-11. (in Polish)

16. Hobbs S. J., Piran C. L. and White P. C. L., 2012 - Motivations and barriers in relation to community participation in biodiversity recording, Journal for Nature Conservation, 20, 364373.

17. Houet T., Verburg P. H. and Loveland T. R., 2010 - Monitoring and modelling landscape dynamics, Landscape Ecology, 25, 163-167.

18. Janovsky D. and Becker G., 2003 - Characteristics and needs of different user groups in the urban forest of Stuttgart, Journal for Nature Conservation, 11, 251-259.

19. Jones-Walters L. and Cil A., 2011 - Biodiversity and stakeholder participation, Journal for Nature Conservation, 19, 327-329. 
20. Kalbarczyk R., 2003 - Oczka wodne w agrosystemach/Small water bodies in agriculture land, Aura, 12, 24-25. (in Polish)

21. Kopeć D., 2007 - Impact of small artificial reservoirs on macrophytes and riparian plant species of upland river (Czarna Maleniecka River, Świętokrzyski Region), TEKA Komisji Ochrony $i$ Kształtowania Środowiska, IV, 93-99.

22. Kornijów R. and Radwan S., 2000 - Zasady zrównoważonego użytkowania i ochrony jezior położonych na terenach wiejskich, Rules of sustainable use and conservation of lakes located in rural areas, in Problemy ochrony i użytkowania obszarów wiejskich o dużych walorach przyrodniczych. Wyd. UMCS, Lublin, 63-70. (in Polish)

23. Kuczera M. and Misztal A., 2008 - Wpływ sposobu użytkowania terenu na jakość wód oczek wodnych/Impact of the way of land use on water quality of small water bodies, Mat. Konger. Krakowska Konferencja Młodych Uczonych, 287-292. (in Polish)

24. Kułak A., 2013 - Kształtowanie środowiska Doliny Bystrzycy w rejonie Zalewu Zemborzyckiego: retrospekcja, diagnoza, oferta/Environmental of Bystrzyca River valley in the area of Zemborzycki Reservoir: retrospection, diagnosis and service, PhD Thesis, not published.

25. Kułak A. and Waryszak P., 2010 - A study of size and structure of tourist movement in 19982010 around the Zemborzycki Reservoir in Lublin, TEKA Komisji Ochrony i Kształtowania Środowiska, VII, 192-202.

26. Kułak A., Sender J. and Maślanko W., 2011 - Analiza kompozycji wnętrza krajobrazowego z oczkiem wodnym, w sąsiedztwie Zalewu Zemborzyckiego w Lublinie/Analysis of the landscape interior composition with a small water body, in the neighborhood of Zemborzycki Reservoir in Lublin, Episteme, 12, 1, 53-61, Kraków. (in Polish)

27. Maślanko W., Sender J. and Kułak A., 2011 - Hydrobotaniczna charakterystyka małych zbiorników wodnych w dolinie rzeki Ciemięgi na odcinku Jastków - Snopków/Hydrobotanical characterization of ponds situated between the villages of Jastków and Snopków in the Ciemięga River valley, Episteme, Kraków 12, 1, 71-79. (in Polish)

28. Mioduszewski W., 1999 - Ochrona i kształtowanie zasobów wodnych w krajobrazie rolniczym/Protection and formation of water supplies in agricultural landscape, Wyd. IMUZ, Falenty, 126. (in Polish)

29. Mioduszewski W., 2006 - Influence of small water reservoirs on groundwater level, TEKA Komisji Ochrony i Ksztattowania Środowiska, III, 136-140.

30. Patro M. and Zubala T., 2010 - Role and threats of water reservoir in the urban palace and park complex in Puławy, TEKA Komisji Ochrony i Ksztattowania Środowiska - OL. PAN, VII, 297-304.

31. Sender J. and Kułak A., 2010 - Significance and development of small water reservoir in the nearest neighbourhood of Zemborzycki Reservoir in Lublin, Teka Kom, TEKA Komisji Ochrony i Kształtowania Środowiska - OL. PAN, VII, 365-373.

32. Szpakowska B. and Życzyńska-Bałoniak J., 1994 - The role of biogeochemical barriers in water migration of humic substances, Polish Journal of Environmental Studies, 3, 2, 35-41.

33. Verburg P. H., Rounsevell M. D. A. and Veldkamp A., 2006 - Scenario based studies of future land use in Europe, Agriculture, Ecosystems and Environment, 114, 1, 1-6.

34. Volk H., 1992 - Neue Entwicklungen bei der Walderholung in Südwestdeutschland, Forstwissenschaftliches Centralblatt, 111, 5, 282-292. (in German)

35. Wiater J., 2005 - Rola roślinności stref ekotonowych w kształtowaniu jakości wód oczka wodnego/A role of ecotone zones' plants in shaping of water quality of small water body, Journal of Elementology, 10, 3, 2, 843-849. (in Polish) 
36. Wołek J., 1996 - Wystepowanie i rozmieszczenie roślin wodnych i szuwarowych na obszarze zespolu zbiomikow wodnych Czorsztyn-Niedzica i Sromowce/Occurrence and distribution of aquatic and rushes vegetation in the Czorsztyn - Niedzica Sromowe Wyżne, Fragmenty Floristica et Geobotanica, 3, 189-203. (in Polish) 